\section{The influence of intravenous anaesthetics on polymorphonuclear leukocyte function}

Werner Krumholz PD DR MED, Christine Demel DR MED, Sabine Jung DR MED, Gunter Meuthen DR MED, Gunter Hempelmann PROF DR MED
Polymorphonuclear leukocytes (PMNL) play a vital role in the defence against invading bacteria. It is known that some anaesthetics inhibit PMNL function and, thus, possibly enhance perioperative infection. We investigated the effect of methohexitone, flunitrazepam, and droperidol on three bactericidal PMNL functions, i.e., superoxide anion production, hydrogen peroxide generation, and activity of released myeloperoxidase, in vitro. Approved photometrical assays were used. Superoxide anion was measured by the reduction of cytochrome $C$, hydrogen peroxide by the horse radish peroxidase catalysed oxidation of phenol red, and myeloperoxidase by the turnover of 2,2'-azino-di(3-ethylbenzthiazoline) sulfonic acid. Methohexitone $(P \leq 0.001)$ and flunitrazepam $(P \leq 0.01)$ inhibited superoxide anion production, and methohexitone $(P \leq 0.01)$ reduced hydrogen peroxide generation but only at concentrations beyond clinical relevance. Droperidol did not cause any alteration of the PMNL functions tested. Consequently, it seems unlikely that the usual doses of methohexitone, flunitrazepam, or droperidol promote bacterial infections in vivo by impairing the activity of myeloperoxidase or by inhibiting the generation of superoxide anion or hydrogen peroxide.

Les leucocytes polynucléaires jouent un rôle essentiel de défense contre linvasion bactérienne. On sait que certains anesthésiques inhibent cette fonction et ainsi pourraient favoriser linfection périopératoire. Nous avons recherché in vitro les effets du méthohéxitone, du flunitrazépam et du dropéridol sur trois

\section{Key words}

ANAESTHETICS, INTRAVENOUS: droperidol, flunitrazepam, methohexitone;

BLOOD: leukocytes.

From the Department of Anaesthesiology and Intensive Care Medicine, Justus-Liebig-University Giessen, Federal Republic of Germany.

Address correspondence to: PD Dr. Werner Krumholz, Abteilung Anaesthesiologie und Operative Intensivmedizin, Klinikstrasse 29, W-6300 Giessen, Germany. Accepted for publication 13th May, 1993. fonctions des polynucléaires, i.e. la production de l'anion superoxyde, la génération du peroxyde dhydrogène et l'activité de la myéloperoxydase. Des épreuves photométriques reconnues ont été utilisées. L'anion superoxyde a été mesuré par la réduction du cytochrome $C$, le peroxyde d'hydrogène par l'oxydation catalytique du rouge phénol par la peroxydase du raifort et la myéloperoxydase par la production de l'acide sulfonique 2,2'azino-di(3-éthylbenzthiazoline). Le méthohexitone $(P \leq 0,001)$ et le flunitrazépam $(P \leq 0,01)$ inhibent la production de l'anion superoxyde, et le méthohexitone diminue la génération du peroxyde d'hydrogène mais seulement à des concentrations qui dépassent liusage clinique. Le dropéridol ne cause pas d'altérations des fonctions polynucléaires. Par conséquent, selon toute probabilité, les doses usuelles de méthohexitone, de flunitrazépam ou de dropéridol ne favorisent pas linfection bactérienne in vivo par altération de l'activité de la myéloperoxydase ou par l'inhibition de la génération de l'anion superoxyde ou du peroxyde dhydrogène.

In spite of the availability of potent antibiotics perioperative infection is still an important clinical problem. In humans, bacteria are confronted with a complex defence system which, above all, consists of polymorphonuclear leukocytes (PMNL). Some anaesthetics may disturb PMNL function. The mechanism responsible for this effect is still unknown. At the beginning of this century Graham ${ }^{1}$ described the depression of phagocytosis caused by ether. Since that time researches have been conducted and reviews of the most important results in this field were published by Stevenson et al. ${ }^{2}$ and by Kress and Eberlein. ${ }^{3}$ Despite this, many questions concerning the influence of anaesthetics on PMNL functions remain unanswered. We studied the action of methohexitone, flunitrazepam, and droperidol on superoxide anion formation, hydrogen peroxide production, and activity of released myeloperoxidase in vitro. Superoxide anion, hydrogen peroxide, and myeloperoxidase are of interest because they are important components of the oxygen-dependent bactericidal system with which PMNL are equipped. 


\section{Methods}

The permission to conduct the study was obtained from the ethical committee of the medical faculty of JustusLiebig-University Giessen.

\section{Blood samples}

Heparinised venous blood samples ( $10 \mathrm{u}$ heparin-sodium $\mathrm{ml}^{-1}$; Sigma, Deisenhofen) were obtained from ten healthy male volunteers (age: $29 \pm 4 \mathrm{yr}$; body weight: $75 \pm 8 \mathrm{~kg}$; height: $1.80 \pm 0.05 \mathrm{~m}$ (mean and SD).

\section{Isolation of PMNL}

The PMNL were isolated with a modification of a method described by Hjorth et al. ${ }^{4}$ Percoll $55 \%$ and Percoll $74 \%$ were produced by diluting isotonic Percoll (Sigma, Deisenhofen) with normal saline solution. Four $\mathrm{ml}$ Percoll 55\% were poured into a polystyrene tube and underlayered with $4 \mathrm{ml}$ Percoll $74 \%$ and overlayered with $4 \mathrm{ml}$ heparinised blood and centrifuged at $350 \times \mathrm{g}$ for $20 \mathrm{~min}$ at $20^{\circ} \mathrm{C}$. The PMNL band was then carefully removed and suspended in $10 \mathrm{ml}$ phosphate buffered saline (PBS; Gibco, Karlsruhe). After centrifugation at 350 $X \mathrm{~g}$ for $10 \mathrm{~min}$ at $20^{\circ} \mathrm{C}$ the supernatant fluid was decanted. The few erythrocytes contaminating the pellet were lysed by adding $2 \mathrm{ml}$ double-distilled water. After $20 \mathrm{sec}$, isotonia was restored with $1 \mathrm{ml}$ saline $2.7 \%$ (Merck, Darmstadt). After administering $7 \mathrm{ml}$ PBS the tube was centrifuged at $350 \times \mathrm{g}$ for $10 \mathrm{~min}$ at $20^{\circ} \mathrm{C}$ and the supernatant was decanted. The purity of the PMNL yield was microscopically evaluated, and viability was confirmed as $95 \%$ by the trypan blue exclusion test. $^{5}$

\section{Superoxide anion formation}

Superoxide anion production was measured photometrically by the reduction of cytochrome $\mathrm{C}$ using a modification of the method described by Stangel et al. ${ }^{6}$ which is similar to that of Weening et al. ${ }^{7}$ Cytochrome C, 100 mg (type VI; Sigma, Deisenhofen) were dissolved in 30 $\mathrm{ml}$ PBS containing $0.99 \mathrm{~g}$ glucose per $100 \mathrm{ml}$ (Merck, Darmstadt). The solution was portioned and frozen at $-20^{\circ} \mathrm{C}$. Opsonized zymosan was used to stimulate PMNL and was produced by incubating $100 \mathrm{mg}$ zymosan (Sigma, Deisenhofen) with $6 \mathrm{ml} \mathrm{AB}$ pool serum for 30 $\min$ at $37^{\circ} \mathrm{C}$. After washing with saline and centrifugation at $350 \times \mathrm{g}$ for $10 \mathrm{~min}$ opsonized zymosan was resuspended in $10 \mathrm{ml}$ PBS glucose buffer, portioned, and frozen at $-20^{\circ} \mathrm{C}$. Isolated PMNL $\left(0.8 \times 10^{6} \mathrm{ml}^{-1}\right)$ were incubated with the anaesthetic to be tested for $15 \mathrm{~min}$ at $37^{\circ} \mathrm{C}$. Then $500 \mu \mathrm{l}$ zymosan, $150 \mu \mathrm{l} \mathrm{AB}$ pool serum, $250 \mu$ l cytochrome $C$, and $500 \mu l$ PMNL suspension were poured into a test tube. A preparation containing $500 \mu \mathrm{l}$ buffer instead of zymosan was used as zero ad- justment. After incubation for $15 \mathrm{~min}$ at $37^{\circ} \mathrm{C}$ the reaction was stopped by putting the test tube into ice water. After centrifugation, at $350 \times \mathrm{g}$ for $5 \mathrm{~min}$ at $4^{\circ} \mathrm{C}$, extinction of the supernatant was measured photometrically at 546 nm (digitalphotometer $6114 \mathrm{~S}$; Eppendorf, Hamburg). The amount of superoxide anion produced resulted from the extinction coefficient of cytochrome $\mathrm{C}\left(21 \mathrm{mMol}^{-1}\right.$ $\cdot \mathrm{cm}^{-1}$ ) according to the law of Lambert, Beer, and Bouguer. ${ }^{6}$ Preparations containing no anaesthetic were simultaneously measured. The assay was able to detect 0.001 nmol of superoxide anion.

\section{Hydrogen peroxide formation}

Hydrogen peroxide production was determined photometrically using a method described by Stangel et al. ${ }^{6}$ which is a modification of the system mentioned by Pick and Keisari. ${ }^{9}$ The process is based on horse radish peroxidase catalysed oxidation of phenol red by hydrogen peroxide. Phenol red (Sigma, Deisenhofen) was dissolved in double-distilled water $\left(10 \mathrm{mg} \cdot \mathrm{ml}^{-1}\right)$ and horse radish peroxidase (type II: Sigma, Deisenhofen) in PBS glucose buffer $\left(5 \mathrm{mg} \cdot \mathrm{ml}^{-1}\right)$. The PMNL were isolated as described before and were stimulated by opsonized zymosan. The final test preparation consisted of $500 \mu \mathrm{l} z y m-$ osan, $125 \mu \mathrm{l} \mathrm{AB}$ pool serum, $12.5 \mu$ l horse radish peroxidase, $12.5 \mu l$ phenol red, $12.5 \mu$ l sodium azide (200 mM; Merck, Darmstadt), $500 \mu$ l PMNL suspension (2 $\left.\times 10^{6} \mathrm{ml}^{-1}\right)$, and the anaesthetic to be tested. After incubation for $30 \mathrm{~min}$ at $37^{\circ} \mathrm{C}$ the preparation was centrifuged at $350 \times \mathrm{g}$ for $10 \mathrm{~min}$ at $4^{\circ} \mathrm{C}$. After adding $25 \mu$ l sodium hydroxide solution (1.0 normal; Merck, Darmstadt) extinction of the supernatant was measured photometrically at $623 \mathrm{~nm}$. The hydrogen peroxide concentration was determined using a calibration curve previously established. The assay was able to detect 0.001 nmol of hydrogen peroxide.

\section{Activity of released myeloperoxidase}

A modification of the method described by Schmitt et al. ${ }^{10}$ was used to measure the activity of released myeloperoxidase: 1 mM 2,2'-azino-di(3-ethylbenzthiazoline) sulfonic acid (ABTS; Sigma, Deisenhofen) was dissolved in 0.1 $\mathrm{M}$ citrate buffer (Behring, Marburg). The PMNL were isolated as described before $\left(2 \times 10^{6} \mathrm{ml}^{-1}\right)$ and incubated with the respective anaesthetic for $15 \mathrm{~min}$ at $37^{\circ} \mathrm{C}$. Then $0.5 \mu \mathrm{g}$ cytochalasin B (Sigma, Deisenhofen) was added to $100 \mu \mathrm{l}$ PMNL suspension. The preparation was incubated for five minutes at $37^{\circ} \mathrm{C}$. After adding $100 \mu l$ opsonized zymosan further incubation was conducted for $10 \mathrm{~min}$ at $37^{\circ} \mathrm{C}$. Then, $1 \mathrm{ml} \mathrm{ABTS}$ solution was added. After centrifugation at $700 \times \mathrm{g}$ for five minutes at $20^{\circ} \mathrm{C}, 1 \mathrm{ml}$ supernatant was removed and mixed with $1 \mu$ l hydrogen peroxide solution (30\%; Merck, 
TABLE I the influence of various concentrations of methohexitone on PMNL superoxide anion production $\left(\mathrm{nmol} \cdot 10^{-6} \mathrm{PMNL} \cdot \mathrm{min}^{-1}\right)$, hydrogen peroxide generation $\left(\mathrm{nmol} \cdot 10^{-6} \mathrm{PMNL} \cdot \mathrm{min}^{-1}\right.$ ), and myeloperoxidase activity (units $\mathrm{L}^{-1}$ supernatant) in vitro $(n=10$; means $+\mathrm{SD})$

\begin{tabular}{lllll}
\hline \multicolumn{5}{l}{ Methohexitone } \\
\cline { 2 - 5 } & $0 \mu \mathrm{g} \cdot \mathrm{ml^{-1 }}$ & $1.7 \mu \mathrm{g} \cdot \mathrm{ml^{ \prime }}$ & $17 \mu \mathrm{g} \cdot \mathrm{ml}^{-1}$ & $170 \mu \mathrm{g} \cdot \mathrm{ml}^{-1}$ \\
\hline Superoxide anion & 3.003 & 2.465 & 2.562 & $2.245^{*}$ \\
& \pm 0.579 & \pm 0.703 & \pm 0.727 & \pm 0.764 \\
Hydrogen peroxide & 0.851 & 0.832 & 0.794 & $0.665 \dagger$ \\
Myeloperoxidase & \pm 0.500 & \pm 0.598 & \pm 0.482 & \pm 0.406 \\
& 0.650 & 0.461 & 0.480 & 0.598 \\
& \pm 0.221 & \pm 0.151 & \pm 0.219 & \pm 0.329 \\
\hline
\end{tabular}

$* P \leq 0.001$

$\dagger P \leq 0.01$

TABLE II The influence of various concentrations of flunitrazepam on PMNL superoxide anion production (nmol $\cdot 10^{-6} \mathrm{PMNL} \cdot \mathrm{min}^{-1}$ ), hydrogen peroxide generation $\left(\mathrm{nmol} \cdot 10^{-6} \mathrm{PMNL} \cdot \mathrm{min}^{-1}\right.$ ), and myeloperoxidase activity (units $\mathrm{L}^{-1}$ supernatant) in vitro $(n=10$; means $\pm \mathrm{SD})$

\begin{tabular}{lllll}
\hline \multicolumn{5}{l}{ Flunitrazepam } \\
\cline { 2 - 5 } & $0 \mu \mathrm{g} \cdot \mathrm{ml^{-1 }}$ & $0.004 \mu \mathrm{g} \cdot \mathrm{m}^{-1}$ & $0.04 \mu \mathrm{g} \cdot \mathrm{m}^{-1}$ & $0.4 \mu \mathrm{g} \cdot \mathrm{m}^{-1}$ \\
\hline Superoxide anion & 3.003 & 2.553 & 2.524 & $2.412^{*}$ \\
& \pm 0.579 & \pm 0.729 & \pm 0.697 & \pm 0.907 \\
Hydrogen peroxide & 0.851 & 0.845 & 0.829 & 0.823 \\
Myeloperoxidase & \pm 0.500 & \pm 0.524 & \pm 0.509 & \pm 0.523 \\
& 0.650 & 0.513 & 0.441 & 0.498 \\
& \pm 0.221 & \pm 0.188 & \pm 0.169 & \pm 0.204 \\
\hline
\end{tabular}

$* P \leq 0.01$.

Darmstadt). Extinction was measured photometrically at $405 \mathrm{~nm}$. Using a calibration curve previously established with horse radish peroxidase activity of released myeloperoxidase was determined. The assay was able to detect $0.001 \mathrm{mU}$ of peroxidase activity.

The variability of the three assays was $\leq 5 \%$.

\section{Anaesthetics}

The following concentrations were tested:

- Methohexitone (Brevimytal Natrium; Eli Lilly, Bad Homburg, Germany): 1.7, 17 , and $170 \mu \mathrm{g} \cdot \mathrm{ml}^{-1}$.

- Flunitrazepam (Rohypnol; Hoffmann-La Roche, Grenzach-Wyhlen, Germany): 0.004, 0.04, and 0.4 $\mu \mathrm{g} \cdot \mathrm{ml}^{-1}$.

- Droperidol (Dehydrobenzperidol; Janssen, Neuss, Germany): $0.1235,1.235$, and $12.35 \mu \mathrm{g} \cdot \mathrm{ml}^{-1}$.

The medium concentrations ( $17 \mu \mathrm{g}$ methohexitone $\mathrm{ml}^{-1}$, $0.04 \mu \mathrm{g}$ flunitrazepam $\mathrm{ml}^{-1}$, and $1.235 \mu \mathrm{g}$ droperidol $\mathrm{ml}^{-1}$ ) are of clinical relevance. ${ }^{11-13}$

\section{Statistics}

All tests were performed in duplicate and the results were mean values of two estimations. The Pearson Stephens test was used to check normal distribution. The Bartlett test examined homogeneity of variance $(P \leq 0.1)$. If the requirements were met, analysis of variance for repeatedmeasures and Scheffé test were conducted. If the requirements were not fulfilled, Friedman analysis of variance and Miller test were performed. A probability of $P \leq$ 0.05 was regarded as moderately significant, $P \leq 0.01$ as significant, and $P \leq 0.001$ as highly significant.

\section{Results}

Means and standard deviations are specified in Tables I-III.

The high concentration of methohexitone caused an inhibition of superoxide anion production $(P \leq 0.001)$ and a reduction of hydrogen peroxide generation $(P \leq$ 0.01 ). The alterations of myeloperoxidase activity were not statistically significant.

The high concentration of flunitrazepam inhibited superoxide anion generation $(P<0.01)$ but there was no effect on hydrogen peroxide production or myeloperoxidase activity.

Droperidol did not influence the PMNL functions tested.

\section{Discussion}

The human organism has a wide range of mechanisms which provide protection from infection. Immunity to 
TABLE III The influence of various concentrations of droperidol on PMNL superoxide anion production ( $\mathrm{nmol} \cdot 10^{-6} \mathrm{PMNL} \cdot \mathrm{min}^{-1}$ ), hydrogen peroxide generation $\left(\mathrm{nmol} \cdot 10^{-6} \mathrm{PMNL} \cdot \mathrm{min}^{-1}\right.$ ), and myeloperoxidase activity (units $\mathrm{L}^{-1}$ supernatant) in vitro $(n=10$; means $\pm \mathrm{SD})$

\begin{tabular}{|c|c|c|c|c|}
\hline & \multicolumn{4}{|l|}{ Droperidol } \\
\hline & $0 \mu g \cdot m I^{-1}$ & $0.1235 \mu \mathrm{g} \cdot \mathrm{ml}^{-l}$ & $1.235 \mu \mathrm{g} \cdot \mathrm{ml}^{-1}$ & $12.35 \mu \mathrm{g} \cdot \mathrm{m} l^{-1}$ \\
\hline \multirow[t]{2}{*}{ Superoxide anion } & 3.459 & 3.231 & 3.387 & 3.138 \\
\hline & \pm 0.517 & \pm 0.483 & \pm 0.710 & \pm 0.550 \\
\hline \multirow[t]{2}{*}{ Hydrogen peroxide } & 1.122 & 1.092 & 1.105 & 0.970 \\
\hline & \pm 0.267 & \pm 0.217 & \pm 0.290 & \pm 0.334 \\
\hline \multirow[t]{2}{*}{ Myeloperoxidase } & 0.449 & 0.394 & 0.425 & 0.425 \\
\hline & \pm 0.164 & \pm 0.138 & \pm 0.118 & \pm 0.177 \\
\hline
\end{tabular}

bacteria depends on the activity of PMNL. ${ }^{14-16}$ After being produced gradually in bone marrow PMNL are delivered to the blood. Attracted by chemotactic factors they permeate the walls of blood vessels and migrate in the direction of bacteria which are subsequently ingested forming phagosomes. These vacuoles are fused with cytoplasmatic granules thus creating phagolysosomes, in which bacteria are usually killed and degraded. A distinction can be made between oxygen-dependent and oxygen-independent bactericidal mechanisms. Oxygen-dependent killing is complex. The PMNL are equipped with an oxidase which probably consists of cytochrome b, flavoprotein, and ubiquinone. This enzyme is able to transport electrons from NADPH to oxygen to form superoxide anion which, presumably, is bactericidal. Beyond that it is the basic material of several other oxygen products being able to kill bacteria. For example, hydrogen peroxide is generated by a dismutase reaction. Compared with other aggressive oxygen metabolites (superoxide anion, singlet oxygen, hydroxyl radical) hydrogen peroxide is stable. Therefore, it can pass through cell membranes and biological fluids without degradation and develop a long-range bactericidal effect. Myeloperoxidase is an enzyme included in the azurophilic granules of PMNL and, among other actions, it catalyses the generation of bactericidal hypochlorous acid.

Methohexitone is a barbiturate frequently used for induction of anaesthesia. In our study high concentrations inhibited superoxide anion production and hydrogen peroxide generation but clinically relevant concentrations had no effect. Myeloperoxidase activity was not influenced by methohexitone. Previous studies with methohexitone on PMNL properties have shown no impairment of chemiluminescence, ${ }^{17-19}$ but that it inhibited PMNL adherence. ${ }^{20}$ Moudgil et $a l^{21}$ and Kress et al. ${ }^{22}$ found an inhibition of migration.

Flunitrazepam is a benzodiazepine used as premedicant, sedative, and induction agent. At high concentrations it depressed superoxide anion generation, but at clinically relevant concentrations it did not. This is com- patible with observations made by Goldfarb et al. ${ }^{23}$ There were no effects of flunitrazepam on hydrogen peroxide production or myeloperoxidase activity. Kress and Weiler ${ }^{24}$ investigated the influence of flunitrazepam on chemiluminescence and at very high concentrations this PMNL function was inhibited.

Droperidol is a substituted butyrophenone possessing neuroleptic, antiemetic, and hypotensive properties. Most often it is used with fentanyl to conduct neuroleptanaesthesia. In the course of our investigation we were unable to detect any disturbance of superoxide anion generation, hydrogen peroxide production, or activity of released myeloperoxidase caused by droperidol. Nakagawara $e t$ al., using a similar method, ${ }^{25}$ noticed a $50 \%$ reduction of superoxide anion generation caused by $32 \mu \mathrm{g} \cdot \mathrm{ml}^{-1}$ of droperidol but this is a concentration far beyond clinical relevance.

In conclusion, our data suggest that the customary doses of methohexitone, flunitrazepam, or droperidol do not enhance bacterial infections by inhibiting superoxide anion production, hydrogen peroxide generation, or myeloperoxidase release. However, clinical recommendations based on in vitro results are problematic on principle. For example, the concentrations of anaesthetics in infected tissues are unknown. Therefore, additional clinical studies should be conducted to support our findings.

\section{References}

1 Graham EA. The influence of ether and ether anesthesia on bacteriolysis, agglutination, and phagocytosis. J Infect Dis 1911; 8: 147-75.

2 Stevenson $G W$, Hall $S C$, Rudnick S, Seleny FL, Stevenson HC. The effect of anesthetic agents on the human immune response. Anesthesiology 1990; 72: 542-52.

3 Kress $H G$, Eberlein $T$. Wirkung von Anästhesie und Operation auf wesentliche Immunfunktionen. Anasthesiologie Intensivmedizin Notfallmedizin Schmerztherapie 1992; 27 393-402.

4 Hjorth $R$, Jonsson $A K$, Vretblad $P$. A rapid method for purification of human granulocytes using Percoll. A com- 
parison with dextran sedimentation. J Immunol Methods 1981; 43: 95-101.

5 Gitter A, Heilmeyer L, Brüschke G. (Eds.). Taschenbuch Klinischer Funktionsprufungen. 10th ed. Stuttgart: Gustav Fischer Verlag, 1978; 285-6.

6 Stangel W, Seidel J, Mirkani J, Behrmann M, Hülsheger $H$. Granulozytenfunktionen in gelagerten Blutkonserven. Beitr Infusionther 1986; 15: 231-52.

7 Weening $R S$, Wever $R$, Roos $D$. Quantitative aspects of the production of superoxide radicals by phagocytizing human granulocytes. J Lab Clin Med 1975; 85: 245-52.

8 Rick $W$. Klinische Chemie und Mikroskopie. 5th ed. Berlin: Springer-Verlag, 1977; 155-68.

9 Pick E, Keisari Y. A simple colorimetric method for the measurement of hydrogen peroxide produced by cells in culture. J Immunol Methods 1980; 38: 161-70.

10 Schmilt $M$, Keller $H U$, Cottier $H$. Qualitative and quantitative assessment of human polymophonuclear leukocyte (PMNL) functions. Beitr Infusionther 1986; 15: 196-230.

11 Sunshine I, Whitwam JG, Fike WW, Finkle B, LeBeau J. Distribution and excretion of methohexitone in man. $\mathrm{Br} J$ Anaesth 1966; 38: 23-8.

12 Lauven PM, Stoeckel H, Schwilden H, Schüttler J. Klinische Pharmakokinetik von Midazolam, Flunitrazepam und Diazepam. Anästhesie Intensivtherapie Notfallmedizin 1981; 16: 135-42.

13 Fischler $M$, Bonnet $F$, Trang $H$, et al. The pharmacokinetics of droperidol in anesthetized patients. Anesthesiology 1986; 64: 486-9.

14 Smolen JE, Boxer LA. Functions of neutrophils. In: Williams WJ, Beutler E, Erslev AJ, Lichtman MA (Eds.). Hematology, 4th ed., New York: McGraw-Hill Publishing Company, 1990; 780-94.

15 Broide DH. Inflammatory cells: structure and function. In: Stites DP, Tert A (Eds.). Basic and Clinical Immunology, 7th ed., London: Prentice-Hall International Inc., 1991: 141-5.

16 Klebanoff SJ. Phagocytic cells: products of oxygen metabolism. In: Gallin JI, Goldstein IM, Snyderman R (Eds.). Inflammation. Basic Principles and Clinical Correlates, New York: Raven Press, 1988; 391-444.

17 White IWC, Gelb AW, Wexler HR, Stiller CR, Keown PA. The effects of intravenous anaesthetic agents on human neutrophil chemiluminescence. Can Anaesth Soc J 1983; 30: 506-11.

18 Kress HG, Eberlein T, Hörber B, Weis KH. Suppression of neutrophil migration and chemiluminescence is due to the sulphur atom in the thiobarbiturate molecule. Acta Anaesthesiol Scand 1989; 33: 122-8.

19 Krumholz W, Kebeiks B, Bachmann-Mennenga B. Veränderung der Granulozyten-Vollblut-Chemilumineszenz durch Thiopental, Methohexital und das Lösungsmittel
Natriumkarbonat. Anaesthesist (Supplement 1) 1989; 38: 133.

20 Krumholz W, Jorgall H, Käbisch $S$, Hempelmann $G$. Narkoseeinleitungsmittel und Granulozytenadhärenz. Anästhesie Intensivtherapie Notfallmedizin 1988; 23: 69-72.

21 Moudgil GC, Allan RB, Russell RJ, Wilkinson PC. Inhibition, by anaesthetic agents, of human leucocyte locomotion towards chemical attractants. Br J Anaesth 1977; 49: 97-105.

22 Kress $H G$, Segmüller $R$. Intravenöse Anaesthetika und Motilităt humaner neutrophiler Granulozyten in vitro. Anaesthesist 1987; 36: 356-61.

23 Goldfarb G, Belghiti J, Gautero H, Boivin P. In vitro effect of benzodiazepines on polymorphonuclear leukocyte oxidative activity. Anesthesiology 1984; 60: 57-60.

24 Kress HG, Weiler $R$. Benzodiazepine und Chemilumineszenz neutrophiler Granulozyten in vitro: Vergleich mit dem Antagonisten Flumazenil. Anaesthesist (Supplement). 1989; 38: 295.

25 Nakagawara M, Hirokata Y, Yoshitake J. Effects of anesthetics on superoxide releasing activity of human polymorphonuclear leukocytes. Masui 1985; 34: 754-9. 